\title{
EVALUATION OF MICROBIOLOGICAL QUALITY OF COLOSTRUM
}

\author{
Svetlana Baltrukova ${ }^{1,2^{*}}$, Jelena Zagorska ${ }^{2}$, Indra Eihvalde ${ }^{3}$ \\ ${ }^{\prime}$ Institute of Food Safety, Animal Health and Environment “BIOR”, Lejupes iela 3, Riga, Latvia, \\ e-mail: svetlana.baltrukova@gmail.com \\ ${ }^{2}$ Faculty of Food Technology, Latvia University of Life Sciences and Technologies, Rigas iela 22, Jelgava, Latvia \\ ${ }^{3}$ Research Study Farm “Vecauce”, Latvia University of Life Sciences and Technologies, Akademijas iela 11A, Vecauce, \\ Vecauces pagasts, Auces novads, Latvia
}

\begin{abstract}
Bovine colostrum is an important source of different biologically active compounds: immunoglobulins, lactoferrin, lysozyme, lactoperoxidase etc., therefore vital for a dairy calf's ability to survive. There is the lack of information about microbiological quality of colostrum. Still it is very important parameter, which can be significant for calf mortality and antibodies absorption rate, the aim of the study was to evaluate microbiological quality of colostrum obtained from Latvian cows. Colostrum samples $\left(\mathrm{n}=20,50 \mathrm{~mL}^{-1}\right)$ were collected in conventional farm with 500 cows (Zemgale, Latvia) during December 2018 to January 2019 one hour after calving. Samples were immediately frozen $\left(-19 \pm 1{ }^{\circ} \mathrm{C}\right.$, within $\left.30 \mathrm{~min}\right)$ and delivered to the laboratory. The colony forming units (LVS EN ISO 4833-1:2013) and presence of $\beta$-glucuronidase positive Escherichia col (LVS EN ISO 16649-2:2007) were detected in colostrum samples. Descriptive statistics were used for data analysis. The average total plate count of analysed colostrum samples was $5.62 \log \mathrm{CFU} \mathrm{mL} \mathrm{m}^{-1}$, colony forming units ranged from 4.97 to $5.90 \log \mathrm{CFU} \mathrm{mL} \mathrm{m}^{-1}$. In the current research $\beta$-glucuronidase positive Escherichia coli $\mathrm{CFU}$ ranged from $>1$ to $8300 \mathrm{~mL}^{-1}$ in colostrum sample. Research results associated with low antibodies absorption rate by calf and high risk of diarrhoea in the farm.
\end{abstract}

Keywords: colostrum, total plate count, Ig concentration

\section{Introduction}

Bovine colostrum is an important source of different biologically active compounds: immunoglobulins (Ig), lactoferrin, lysozyme, lactoperoxidase etc., therefore vital for a dairy calf's ability to survive. Studies show that the highest concentration of biologically active components in colostrum is collected in cows at the first milking after calving (Hurley, Theil, 2011), reporting maximum concentration in the first four hours (Sacerdote et al., 2013) to six hours (Borad, Singh, 2018) after calving.

The concentration of Ig in bovine colostrum affects the passive immunity acquisition in new-born calves (Swan et al., 2007; Quigley et al., 2013; Mann et al., 2016; Arsenopoulos et al., 2017). Therefore, accurate measurement of Ig is essential to provide healthy growth of the younger generation on the dairy farms, which will be able to provide new-born calves with necessary

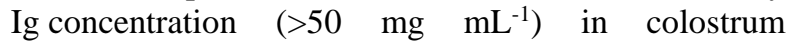
(Lago et al., 2018). Quigley et al. (2013), Morrill et al. (2015), Yaylak, Yavuz, Özkaya (2017) and other authors used Brix refractometer to estimate Ig concentration in colostrum. Authors concluded that Brix measurement of total solids in fresh colostrum is a sufficiently accurate method for estimating IgG concentration, which is confirmed by the use of alternative methods in studies. Quigley et al. (2013) suggested, that predicted IgG concentration in colostrum based on Brix percentage is variable. Current industry recommendations designate discarding colostrum should contain $<50 \mathrm{mg}$ of $\mathrm{IgG} \mathrm{mL}^{-1}$ and $>5 \log 10 \mathrm{CFU} \mathrm{mL} \mathrm{m}^{-1}$ total bacteria count (Morrill et al., 2012; Quigley et al., 2013; Morrill et al., 2015; Yaylak et al., 2017).

Colostrum bacterial contamination is another important quality parameter. Microbiologically contaminated colostrum can reduce animal performance as well as increase morbidity and mortality rates in the farms (Elizondo-Salazar et al., 2010; Mohammed et al., 2018). Microorganisms can bind to free immunoglobulins and block absorption of these molecules by enterocytes (Morrill et al., 2012; Santos et al., 2017).

Last data reported about microbiological quality of colostrum from Latvian dairy herds is from 2008, when microorganisms count ranged from $4.3 \mathrm{log}$ to $6.0 \log$ CFU mL $\mathrm{mL}^{-1}$ (Gala zinojums, 2008).

Information about microbiological quality of colostrum in Latvia is limited and outdated; still it is very important parameter and can be significant factor detecting calf mortality rate. Therefore, the aim of the study was to evaluate microbiological quality of colostrum obtained from Latvian cows.

\section{Materials and Methods}

Colostrum was collected from Holstein Black cows, lactation period ranged from: $1^{\text {st }}$ to $4^{\text {th }}$. Colostrum samples $(n=20,50 \mathrm{~mL})$ were collected in conventional farm with 500 cows (Zemgale, Latvia). Colostrum samples were classified according lactation number $1^{\text {st }}$ $(n=4), 2^{\text {nd }}(n=8), 3^{\text {rd }}(n=5)$ and $4^{\text {th }}(n=3)$. Colostrum samples were collected from December 2018 to January 2019 one hour after calving according LVS EN ISO 707:2011 Milk and milk products - Guidance on sampling. Samples at $20{ }^{\circ} \mathrm{C}$ were immediately after collection used for immunoglobulins and total solids content detection.

Samples for microbiological analysis were immediately frozen $\left(-19 \pm 1{ }^{\circ} \mathrm{C}\right.$, within $\left.30 \mathrm{~min}\right)$ and delivered to the laboratory, stored less than 30 days before analysis. Before microbiological tests, samples were removed from freezer, thawed and homogenized in a water bath $\left(\sim 45 \pm 2{ }^{\circ} \mathrm{C}\right)$, then prepared according the following standards: LVS EN ISO 6887-1 and 5:2011 Microbiology of food and animal feeding stuffs - 
Preparation of test samples, initial suspension and decimal dilutions for microbiological examination Part 1: General rules for the preparation of the initial suspension and decimal dilutions, Part 5: Specific rules for the preparation of milk and milk products.

The total plate count (TPC) was detected in colostrum samples according to standard LVS EN ISO 4833-1:2013 Microbiology of the food chain. Horizontal method for the enumeration of microorganisms. Part 1: Colony count at $30^{\circ} \mathrm{C}$ by the pour plate technique; presence of Escherichia coli (E.coli) according to LVS EN ISO 16649-2:2007 Microbiology of food and animal feeding stuffs. Horizontal method for the enumeration of beta-glucuronidase positive Escherichia coli. Part 2: Colony-count technique at $44{ }^{\circ} \mathrm{C}$ using 5-bromo-4chloro-3-indolyl beta-D-glucuronide.

The colostrometer (COLOSTROMETER ${ }^{\mathrm{tm}}$ Biogenics, USA) was used for evaluation of Ig concentration in $\mathrm{mg} \mathrm{mL}^{-1}$. Percentage of Ig in colostrum was measured using an optical Brix refractometer (Model BX, UK) with a range of 0 to $34 \%$ Brix.

Descriptive statistics were used for data analysis.

\section{Results and Discussion}

One of the most important factors for bovine neonatal immune function is the first feeding of colostrum. Colony forming units is very important parameter, which indicate quality of many products, colostrum isn't exception. One of the quality criteria for bovine colostrum is the total plate count based on Commission Regulation lays down the same hygiene requirements for bovine colostrum quality as for raw bovine milk, TPC does not exceed $100000 \mathrm{CFU} \mathrm{mL}^{-1}$ (>5 $\log \mathrm{CFU} \mathrm{mL} \mathrm{m}^{-1}$ ) (European Commission, 2006). Previous studies have shown a wide range of microorganisms count in colostrum, ranged from 1.4 to

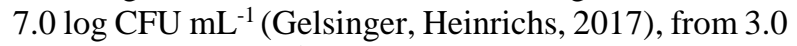
to $6.8 \log \mathrm{CFU} \mathrm{mL} \mathrm{mL}^{-1}$ (Morrill et al., 2012), from 5.4 to $7.2 \log \mathrm{CFU} \mathrm{mL} \mathrm{mL}^{-1}$ (Dunn et al., 2017), from 1.86 to

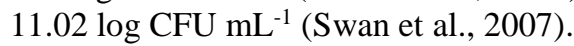

During the research, samples were divided into two groups by TPC and its correspondence to Regulation. Colony forming units and distribution of analysed samples are shown in Table 1.

Table 1

Proportion of colostrum samples by colony forming units

\begin{tabular}{|c|c|c|c|}
\hline Group & $\begin{array}{c}\text { Proportion } \\
\%\end{array}$ & $\begin{array}{c}\min \\
\log \text { CFU } \\
\text { mL }^{-1}\end{array}$ & $\begin{array}{c}\text { max } \\
\log \text { CFU } \\
\text { mL }^{-1}\end{array}$ \\
\hline 1 & 5 & 3.97 & 3.97 \\
\hline 2 & 95 & 5.08 & 5.90 \\
\hline
\end{tabular}

Among the colostrum samples in the current study, there was a wide variation of TPC, from 3.97 to $5.90 \log \mathrm{CFU} \mathrm{mL}^{-1}$. Other authors reported more significant total plate count variations from 3 to 6.80 $\log$ CFU mL-1 (Morrill et al., 2012) and from 2.34 to $6.94 \log \mathrm{CFU} \mathrm{mL}-1$ (Quigley et al., 2013).
In this study only $5 \%$ of the colostrum samples meet microbiology safety criteria that matched $<5 \mathrm{log}$ CFU mL $\mathrm{mL}^{-1}$, in $95 \%$ of samples total bacterial count ranged from 5.09 to $5.90 \log \mathrm{CFU} \mathrm{mL} \mathrm{mL}^{-1}$. Similar results, high percentage of microbiologically contaminated colostrum, that exceed higher permissible limit of guidelines for microbial criteria, were obtained in other studies: overall $81 \%$ samples $(n=1239)$ (Dunn et al., 2017).

Gelsinger \& Heinrichs (2017) proved, that high TPC, detected in analysed dairy farm (average $5.62 \log \mathrm{CFU} \mathrm{mL}^{-1}$ ), can negatively influence Ig absorption by calves. Microbiological contamination is an indicator of colostrum quality. In the current study it was not satisfactory and according to Arsenopoulos et al. (2017) can be a reason for neonatal calf diarrhoea, still storage of colostrum practised in farms for the longest period of time can enhance negative influence, promoting bacteria growth. Morrill et al. (2012) reported about TPC reduction by $0.5 \mathrm{log}$ in colostrum samples after freezing, in comparison with the samples that were stored chilled.

Authors (Elmoslemany et al., 2010; Zhao et al., 2010; Sacerdote et al., 2013; Mann et al., 2016) mentioned different factors influencing bacteria count in colostrum - stage of lactation is one of them. Average total plate count and E. coli distribution of cow's lactation are show in Table 2.

Table 2

Distribution of colostrum samples by total and E. coli bacteria count

\begin{tabular}{lccc}
\hline \multirow{2}{*}{$\begin{array}{l}\text { Lactation } \\
\text { period }\end{array}$} & $\begin{array}{c}\text { Proportion } \\
\%\end{array}$ & $\begin{array}{c}\text { Average } \\
\text { TPC }\end{array}$ & $\begin{array}{c}\text { Average } \\
\text { E.coli }\end{array}$ \\
\cline { 3 - 4 } & & $\begin{array}{c}\text { Log CFU } \\
\mathbf{m L}^{-1}\end{array}$ & $\begin{array}{c}\text { Log CFU } \\
\text { mL }^{-1}\end{array}$ \\
\hline mean & 100 & 5.62 & 2.64 \\
\hline $1^{\text {st }}$ & 20 & 5.76 & 3.32 \\
$2^{\text {nd }}$ & 40 & 5.49 & 1.43 \\
$3^{\text {rd }}$ & 25 & 5.63 & 1.52 \\
$4^{\text {th }}$ & 15 & 5.66 & 0.88 \\
\hline
\end{tabular}

According to our results, the highest total bacteria count was in colostrum obtained after $1^{\text {st }}$ lactation (5.76 log CFU $\mathrm{mL}^{-1}$ ), followed by samples obtained from $3^{\text {rd }}$ and $4^{\text {th }}$ lactation period with average bacteria count ranged from 5.62 to $5.65 \log \mathrm{CFU} \mathrm{mL}^{-1}$, respectively. Lowest TPC was determined in colostrum after $2^{\text {nd }}$ lactation $-5.49 \log \mathrm{CFU} \mathrm{mL} \mathrm{mL}^{-1}$. Other authors presented contradictory results, higher bacteria count after $3^{\text {rd }}$ lactation, were presented in Sacerdote et al. (2013) study, in colostrum after $2^{\text {nd }}$ and $3^{\text {th }}$ lactation period total bacteria count increased from $7.5 \mathrm{log}$ to $7.8 \log$ CFU mL $\mathrm{mL}^{-1}$. Different tendency was detected by Morrill et al. (2012), who reported lower TPC in colostrum obtained after $2^{\text {nd }}$ lactation, comparing to $3^{\text {rd }}$ lactation colostrum. According to the research results bacteria count significantly increased after $1^{\text {st }}$ lactation from $4.5 \log$ to $4.7 \log$ in $2^{\text {nd }}$ lactation samples, but decreased till $4.3 \log \mathrm{CFU} \mathrm{mL} \mathrm{mL}^{-1}$ after $3^{\text {th }}$ lactation, respectively (Morrill et al. 2012). Our results can be 
explained with tissue damage in older animals and easier microorganism migration inside.

Enterobacteria presence was detected in $100 \%$ of the samples, results can be explained with poor hygiene rules adherence (Santos et al., 2017) in the farm. In the current study, used $\beta$-glucuronidase positive Escherichia coli count determination method allows to identify about $90 \%$ to $100 \%$ E. coli strains (Public Health England, 2014). E. coli is commonly used as alternative marker of poor sanitary practice, direct and indirect fecal bacteria contamination. Levels of these bacteria often act as an indirect measure of the potential for dangerous fecal pathogens to be present in food (Neeliah, Arlandoo, Kureemun, 2016).

Presence of $\beta$-glucuronidase positive E. coli was identified in $85 \%$ of colostrum samples analysed during research (Table 3 ).

Table 3

Proportion of colostrum samples by $E$. coli count

\begin{tabular}{lccc}
\hline $\begin{array}{l}\text { Group } \\
\text { Log CFU }\end{array}$ & $\begin{array}{c}\text { Proportion } \\
\text { \% }\end{array}$ & min & max \\
\cline { 3 - 4 } mL $^{-1}$ & & $\begin{array}{c}\text { Log CFU } \\
\mathbf{m L}^{-1}\end{array}$ & $\begin{array}{c}\text { Log CFU } \\
\mathbf{m L}^{-1}\end{array}$ \\
\hline No growth & 15 & - & - \\
$<1$ & 35 & 0.00 & 0.85 \\
$1-1.99$ & 40 & 1.08 & 1.93 \\
$2-2.99$ & 5 & 2.23 & 2.23 \\
$>3$ & 5 & 3.92 & 3.92 \\
\hline
\end{tabular}

Compared to other authors results proportion of colostrum samples by $E$. coli count is significantly higher $(\mathrm{p}<0.05)$ than those reported by Mohammed et al. (2018) - 12\% and Phipps et al. (2016) - 37\% study results. In the current research $E$. coli count ranged from 0.00 to $3.92 \log \mathrm{CFU} \mathrm{mL} \mathrm{mL}^{-1}$, and corresponds to US standards of bacterial contamination of colostrum $<4 \log \mathrm{CFU} \mathrm{mL} \mathrm{mL}^{-1}$. Other authors data about total coliform count 0.00-4.87 log (Quigley et al., 2013), 3.78-6.91 log (Gelsinger, Heinrichs, 2017) and 0.00-9.48 log CFU mL ${ }^{-1}$ (Swan et al., 2007) confirm our research results.

In the current study, significant number of samples met the industry recommendations in terms of total coliform count $(100 \%)$, however; only $5 \%$ of the analysed colostrum samples were within limits in terms to TPC. Colostrum microbiological contamination can occur in different ways: milk can be contaminated with commensal bacteria from the teat skin, epithelial lining of teat canal, the lactiferous duct while it is being excreted of milk during collection, processing, handling and storage (Alegbeleye et al., 2018). Some countries practise heat treatment as for improving microbiological quality of colostrum, as for reducing bacterial infection in neonatal calves and increasing Ig absorption (Elizondo-Salazar et al., 2010; Gelsinger, Heinrichs, 2017). For ensuring calves with high quality colostrum such experience can be recommended for Latvian dairy herds.

The level of Ig in bovine colostrum after first milking can be highly variable, from 60 to $100 \mathrm{mg} \mathrm{mL}^{-1}$ (Sanchez et al., 2004), from 1.4 to $204 \mathrm{mg} \mathrm{mL}^{-1}$ (Dunn et al., 2017), from $<1$ to $200 \mathrm{mg} \mathrm{mL}^{-1}$ (Morrill et al., 2012), from 12.8 to $154.3 \mathrm{mg} \mathrm{mL}^{-1}$ (Morrill et al., 2015). The concentration of immunoglobulins in analysed colostrum samples ranged from 40 to $118 \mathrm{mg} \mathrm{mL}^{-1}$, mean value $-85 \mathrm{mg} \mathrm{mL}^{-1}$ (Figure 1).

Other authors reported significant $(\mathrm{p}<0.05)$ lower Ig concentration in colostrum - $63.6 \mathrm{mg} \mathrm{mL}^{-1}$ (Lago et al., 2018). Only in one analysed colostrum sample Ig concentration was less than $50 \mathrm{mg} \mathrm{mL}^{-1}$ $40 \mathrm{mg} \mathrm{mL}^{-1}$, but other $95 \%$ of samples contained above $53 \mathrm{mg} \mathrm{mL} \mathrm{mL}^{-1}$ of $\mathrm{Ig}$. Other studies showed lower Ig concentration $\left(<50 \mathrm{mg} \mathrm{mL}^{-1}\right)$ in individual colostrum samples, overall 44\% samples (Dunn et al., 2017), 30\% (Morrill et al., 2012), 17\% (Yaylak et al., 2017) were not according recommendations, but mean concentration of Ig still exceeds industry recommendations for $\mathrm{IgG}$ concentration in bovine colostrum.

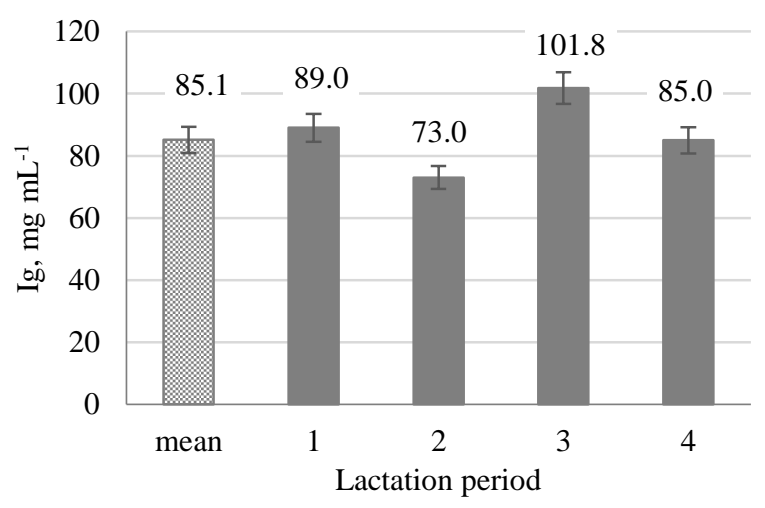

Figure 1. Mean Ig concentration in colostrum samples

Researchers found a relationship between lactation and Ig concentration in colostrum (Zhao et al., 2010; Morrill et al., 2012; Yaylak et al., 2017). The first lactation cows were found to have significantly lower IgG concentration in colostrum samples compared to cows in the second or higher lactation. This may be associated to increased tissue damage in older animals that increase the leakage of Ig from the serum in milk (as observed in somatic cells) (Sanchez et al., 2004). Colostrum production is often lower in cattle of the first lactation, which implies less development of the mammary glands and potentially reduces the transport ability of $\operatorname{IgG}$ to the mammary gland (Morrill et al., 2012).

Comparing Ig concentration after $1^{\text {st }}$ and $2^{\text {nd }}$ lactation, results were similar to Yaylak et al. (2017), higher Ig concentration was after $1^{\text {st }}$, comparing to $2^{\text {nd }}$ lactation 94.1 and $88.03 \mathrm{mg} \mathrm{mL}^{-1}$, respectively.

Contradictory results obtained by Morrill et al. (2012), Ig concentration $\left(95.5 \mathrm{mg} \mathrm{mL}^{-1}\right)$ after $3^{\text {rd }}$ lactations was higher compared with first two lactations $-1^{\text {st }}$ (42.4 $\left.\mathrm{mg} \mathrm{mL}^{-1}\right)$ and $2^{\text {nd }}\left(68.6 \mathrm{mg} \mathrm{mL}^{-1}\right)$. Latvian researchers' results detected the mean concentration of Ig tends to decrease with each subsequent lactation (from $1^{\text {st }}$ to $4^{\text {th }}$ ) in the colostrum $-101.3 \mathrm{mg} \mathrm{mL}^{-1}$, $89.6 \mathrm{mg} \mathrm{mL}^{-1}, 88.1 \mathrm{mg} \mathrm{mL}^{-1}$ and $89.7 \mathrm{mg} \mathrm{mL}^{-1}$ (Eihvalde et al., 2012). 
In the current study, higher Ig concentration in colostrum after $1^{\text {st }}$ lactation can be explained with high TPC and E.coli count in colostrum, which resulted in a mammary gland protection mechanism.

Obtained results did not reveal any tendency to reduce or increase Ig concentration depending on the lactation period as other authors reported. This may be related to a small number of samples, breed, nutrition, length of the dry period of cows, vaccination and other factors (Dunn et al., 2017).

Figure 2 shows the distribution of Brix refractometer readings for the analysed samples. The percentage of Ig in colostrum in the analysed farm ranged from 20 to $32 \%$, mean $24 \%$ Brix.

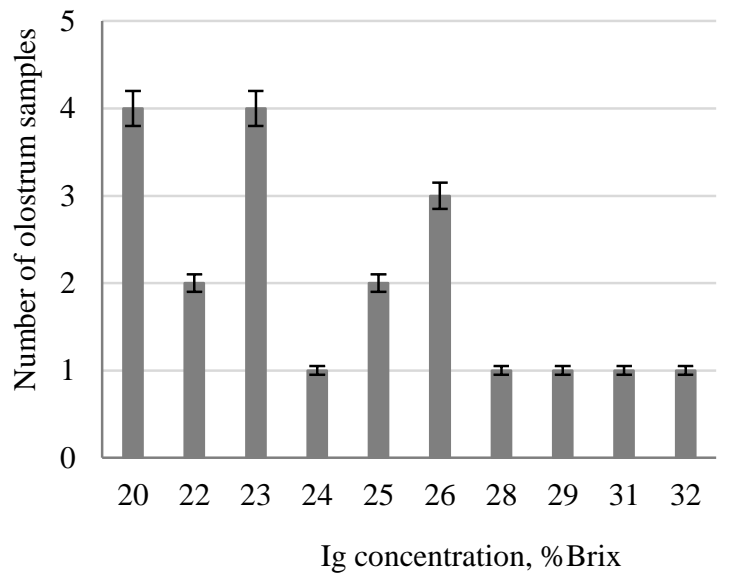

Figure 2. Distribution of Ig concentrations (\% Brix) by the number of samples

The distribution of samples was the same as in a case with colostrometer measurements: higher concentration (28\%) was in $3^{\text {rd }}$ colostrum, then follow $1^{\text {st }}(26 \%)$, $4^{\text {th }}(22 \%)$, and $2^{\text {nd }}(21 \%)$.

Recommended concentration $21 \%$ is considered the break point for high-quality $\left(>50 \mathrm{mg} \mathrm{mL}^{-1}\right)$ bovine colostrum (Morrill et al., 2012; Quigley et al., 2013). Based on this recommendation, $80 \%$ of the samples should be included in a high-quality colostrum group. Other authors reported lower mean Ig concentration $21.24 \%$ (Morrill et al., 2015), - 23.8\% Brix (Quigley et al., 2013), - 20.3\% (Lago et al., 2018). Yaylak et al. (2017) report higher concentration of $\mathrm{Ig}-$ $24.61 \%$.

Obtained research results showed poor microbiological quality of colostrum regarding total plate count in the colostrum from analysed dairy farm. Nowadays there is no control for microbiological quality of colostrum in Latvian dairy farms. However it can be a determinative factor in mortality rate of calves, as for passive immunity transfer, still bacteria can bind to free immunoglobulins in the intestinal lumen and block absorption of these molecules by enterocytes (Santos et al., 2017). For comprehensive assessment of Latvian colostrum quality, number of analysed samples should be increased and further research should be done.

\section{Conclusions}

Poor microbiological quality of colostrum obtained from analysed farm was proved through a high total plate count (average - $5.65 \log \mathrm{CFU} \mathrm{mL}^{-1}$ ) exceeding permissible level for such product and Enterobacteria presence in $100 \%$ of analysed samples.

Despite sufficient concentration of Ig in analysed samples (mean $85.1 \mathrm{mg} \mathrm{mL}^{-1}$ and $24 \%$ Brix) colostrum microbiological quality should be improved.

Research results can be associated with low Ig absorption rate by calves and high risk of diarrhoea in the farm.

\section{Acknowledgment}

The research was supported by Institute of Food Safety, Animal Health and Environment "BIOR".

\section{References}

1. Alegbeleye O. O., Guimarães J. T., Cruz A. G., Sant'Ana A.S. (2018) Hazards of a 'Healthy' Trend? An appraisal of the risks of raw milk consumption and the potential of novel treatment technologies to serve as alternatives to pasteurization. Trends in Food Science and Technology, Vol. 82, p. 148-166.

2. Arsenopoulos K., Theodoridis A., Papadopoulos E. (2017) Effect of colostrum quantity and quality on neonatal calf diarrhoea due to Cryptosporidium Spp. infection. Comparative Immunology, Microbiology and Infectious Diseases, Vol. 53, p. 50-55.

3. Borad S.G., Singh A.K. (2018) Colostrum immunoglobulins: Processing, preservation and application aspects. International Dairy Journal, Vol. 85, p. 201-210.

4. European Commission Regulation (EC) No. 1662/2006 Amending Regulation No. 853/2004, Official Journal of the European Union, [accessed on 20.03.2019]. Available: https://eur-lex.europa.eu/legalcontent/GA/TXT/?uri=CELEX:32006R1662

5. Dunn A., Ashfield A., Earley B., Welsh M., Gordon A., Morrison S.J. (2017) Evaluation of factors associated with immunoglobulin $\mathrm{G}$, fat, protein, and lactose concentrations in bovine colostrum and colostrum management practices in grassland-based dairy systems in Northern Ireland. Journal of Dairy Science, Vol. 100 (3), p. 2068-2079.

6. Eihvalde I., Kairiša D., Zagorska J. (2012) Analysis of factors influencing immunoglobulin concentration in colostrum of dairy cows. Scientific Papers, Animal Science Series, Vo. 57 (94), p. 256-259.

7. Elizondo-Salazar J.A., Jayarao B.M., Heinrichs A.J. (2010) Effect of heat treatment of bovine colostrum on bacterial counts, viscosity, and immunoglobulin G concentration. Journal of Dairy Science, Vol. 93 (3), p. 961-967.

8. Gala ziņojums (2008) Latvijā iegūtā govju jaunpiena nekaitīguma kritēriju noteikšana. [accessed on 20.03.2019]. Available: https://www.llu.lv/zps_projekti?page=20

9. Gelsinger S.L., Heinrichs A.J. (2017) Comparison of immune responses in calves fed heat-treated or unheated colostrum. Journal of Dairy Science, Vol. $100(5)$, p. 4090-4101.

10. Hurley W.L., Theil P.K. (2011) Perspectives on immunoglobulins in colostrum and milk. Nutrients, Vol. 3(4), p. 442-474. 
11. Lago A., Socha M., Geiger A., Cook D., Silva-del-Río N., Blanc C., Quesnell R., Leonardi C. (2018) Efficacy of colostrum replacer versus maternal colostrum on immunological status, health, and growth of preweaned dairy calves. Journal of Dairy Science, Vol. 101 (2), p. 1344-1354.

12. Mann S., Leal Yepes F.A., Overton A.L., Lock T.R., Lamb J.J., Wakshlag S.V., Nydam D.V. (2016) Effect of dry period dietary energy level in dairy cattle on volume, concentrations of immunoglobulin G, insulin, and fatty acid composition of colostrum. Journal of Dairy Science, Vol. 99 (2), p. 1515-1526.

13. Mohammed S.A., Marouf S.A., Erfana A.M., El-Haleem El-Jakee J.K., Hessain A.M., Dawoud T.M., Kabli S.A., Moussa I.M. (2018) Risk factors associated with E. Coli causing neonatal calf diarrhea. Saudi Journal of Biological Sciences, Article in press.

14. Morrill K.M., Robertson K.E., spring H.D., Robinson M.M., Tyler A.L. (2015) Validating a refractometer to evaluate immunoglobulin G concentration in jersey colostrum and the effect of multiple freeze-thaw cycles on evaluating colostrum quality. Journal of Dairy Science, Vol. 98 (1), p. 595-601.

15. Morrill K.M., Conrad E., Lago A., Campbell J., Quigley J., Tyler H. (2012) Nationwide evaluation of quality and composition of colostrum on dairy farms in the United States. Journal of Dairy Science, Vol. 95(7), p. 3997-4005.

16. Neeliah S.A., Arlandoo J.D.L., Kureemun B. R. (2016) Ready to eat salads in selected retail outlets of Mauritius: An assessment of their hygiene status through enumeration of $\beta$-glucuronidase positive Escherichia Coli. International Food Research Journal, Vol 23 (6), p. 2661-2667.

17. Phipps A.J., Beggs D.S., Murray A.J., Mansell P.D., Stevenson M.A., Pyman M.F. (2016) Survey of bovine colostrum quality and hygiene on Northern Victorian dairy farms. Journal of Dairy Science, Vol 99(11), p. 8981-8990.

18. Public Health England (2014) $\beta$-glucuronidase positive Escherichia Coli: pour plate method microbiology services food water and environmental microbiology standard method enumeration of $\beta$-glucuronidase positive
Escherichia Coli: pour plate method enumeration of $\beta$-glucuronidase positi, [accessed on 20.03.2019]. Available: https://assets.publishing.service.gov.uk/ government/uploads/system/uploads/attachment_data/file /342708/Ecoli_pour_plate.pdf

19. Quigley J.D., Lago A., Chapman C., Erickson P., Polo J. (2013) Evaluation of the Brix refractometer to estimate immunoglobulin $\mathrm{G}$ concentration in bovine colostrum. Journal of Dairy Science, Vol. 96 (2), p. 1148-1155.

20. Sacerdote P., Mussano F., Franchi S., Panerai A.E., Bussolati G., Carossa S., Bartorelli A., Bussolati B. (2013) Biological components in a standardized derivative of bovine colostrum. Journal of Dairy Science, Vol. 96(3), p. $1745-1754$.

21. Sanchez J., Markham F., Dohoo I., Sheppard J., Keefe G., Leslie K. (2004) Milk antibodies against Ostertagia Ostertagi: Relationships with milk $\mathrm{IgG}$ and production parameters in lactating dairy cattle. Veterinary Parasitology, Vol. 120 (4), p. 319-330.

22. Santos G., Silva T.J., Santos F.H.R., Bittar C.M.M. (2017) Nutritional and microbiological quality of bovine colostrum samples in Brazil. Revista Brasileira de Zootecnia, Vol. 46 (1), p. 72-79.

23. Stewart S., Godden S., Bey R., Rapnicki P., Fetrow S., Farnsworth R., Scanlon M., Arnold Y., Muller K., Ferrouillet C. (2005) Preventing bacterial contamination and proliferation during the harvest, storage, and feeding of fresh bovine colostrum. Journal of Dairy Science, Vol 88 (7), p. 2571-2578.

24. Swan H., Godden S., Bey J., Wells R., Fetrow S., ChesterJones H. (2007) Passive transfer of immunoglobulin G and preweaning health in holstein calves fed a commercial colostrum replacer. Journal of Dairy Science, Vol. 90 (8), p. 3857-3866.

25. Yaylak E., Yavuz M., Özkaya S. (2017) The effects of calving season and parity on colostrum quality of holstein cows. Indian Journal of Animal Research, Vol. 51(3), p 594-598.

26. Zhao S., Zhang C., Wang J., Liu G., Bu D., Cheng J., Zhou L. (2010) Variations of immunoglobulins in colostrum and immune milk as affected by antigen releasing devices. Asian-Australasian Journal of Animal Sciences, Vol. 23 (9), 1184-1189. 